\title{
INO80D Gene
}

National Cancer Institute

\section{Source}

National Cancer Institute. INO80D Gene. NCI Thesaurus. Code C125258.

This gene plays a role in ATP-dependent chromatin remodeling. 